UDC 327.8

DODONOVA VIRA,

Borys Grinchenko Kyiv University (Kyiv, Ukraine)

e-mail:v.dodonova@kubg.edu.ua,ORCID 0000-0002-4282-5495

\title{
TANDEM OF POPULISM AND POST-TRUTH AS THE BACKGROUND OF DEVELOPMENT OF THE MODERN DEMOCRACY IN UKRAINE
}

Political science theories and concepts that describe the real political process have always been the empirical basis for political philosophy. According to the author, the 2019 Ukrainian presidential election campaign can best be understood and described using the concepts of "populism" and "post-truth". The paper analyzes the discourse of the concept of "populism", and reveals its content and main features. The need to establish social supervision over the actions of the authorities as a means of countering populism is emphasized. Essential characteristics of the post-truth phenomenon are revealed. The theoretical chain of the terms "verity" - "truth" - "posttruth" is presented. The meme as a unit of post-truth is analyzed. The paper proves that it was the bundle of populism and post-truth that had been the background of the electoral consciousness where the manipulative election technologies of the presidential campaign in Ukraine unfolded.

Keywords: democracy; elections; populism; post-truth; meme.

\section{Introduction}

According to global practice, democratic transit is successful only if there are at least three elections that are recognized as transparent and democratic. In this regard, Ukraine meets these requirements, and in some aspects of democracy it provides an example even to Western countries with a stable and consolidated democracy. Our society has a demand for democratic transformations both in social and political areas, to reduce the gap between power and society, which once again arose after the Revolution of Dignity. In addition to transparency and democratic elections, according to F. Fukuyama, modern democracies must meet the following requirements: availability of three "core political institutions: the state, rule of law and democratic accountability" (Fukuyama, 2019: 16). It is the accountability of the government which is probably the cornerstone of democratic processes in Ukraine. The promises that are constantly given by the authorities are difficult to verify, since there is no objective information about whether something is done or not. The infoglut around the problem renders it impossible to distinguish actually true information. In addition to the infoglut that prevents the establishment of the truth, the patrimonial type of state plays a major role in Ukraine, where natural forms of sociality and dependence on relatives and friends are crucial. That is why democratic accountability exists more as a declarative phenomenon. Ukrainian politicians "hold out" declarative promises, which very often cannot be actually implemented, but which the people listen to. Populism is steadily gaining ground in our country. And amidst the spread of information technology, it is even more fueled by the mass media and produces post-truth

The concept of "post-truth" is steadily becoming part of contemporary academic discourse. In the literature, the term "post-truth" is associated with the work of the prominent Serbian-American writer and playwright Steve Tesich, who used it in The Nation magazine in the context of the Iranian scandal during the Gulf War. The ancient Greeks also appealed to the characteristics of what is now considered to be true post-truth: Xenophon, Heraclitus,

ISSN 1728-9343 (Print)

ISSN 2411-3093 (Online)
Socrates, Protagoras (Abazi, 2017: 10-11). Karl Popper called the activity, similar to the post-true as "falsificationism" (Abazi, 2017: 13). Modern philosopher A. Kirkpatrick believes that "post-truth is our plague. And like the plague, this idea is nothing new. In fact, the so-called posttruth era that we currently endure is little more than the morbid actuality of the postmodern condition." (Kirkpatrick, 2017: 4)

The purpose of the paper is to reveal the significance of the tandem of populism and post-truth in the pre-election presidential campaign in Ukraine in 2019.

\section{Research methods}

The main methods that were useful when writing this paper were the following: discourse analysis, which made it possible to see the range of understanding of the phenomena under consideration, filling the concepts with a specific political, epistemological, and sociocultural meaning; the phenomenological method made it possible to analyze the intentions of mass consciousness during the last presidential elections in Ukraine; the comparative method allowed comparing the manifestations of populism of the pre-election campaigns in European countries.

Results and discussion

The 2019 presidential election provided a number of innovations that require their reinterpretation and appreciation. Only yesterday, the showman Volodymyr Zelenskyi, who had no experience in management and politics before the election, was considered as having poor chances. But unexpectedly he not only made it to the run-off with the acting president Petro Poroshenko, but also won with an unprecedented landslide with $73.22 \%$ against $24.45 \%$. The lion's share of merit in this victory belongs to political technologists who have created a presidential candidate "from nothing."

However, this would not have happened if the state of electoral consciousness of Ukrainians were not prepared to restart power. Such expectations of change are traditional

SKHID No. 3 (161) May-June 2019 
for our society. Let's remind that at one time Petro Poroshenko also won in the first voting, having gained $54.7 \%$ of the votes. It was a huge credit of trust that none of the previous presidents had. Unfortunately, this credit was not justified, as he failed to implement most of his election promises. Therefore, an unusual player appeared at the political Olympus - an artist, some "Mister X", which, contrary to common sense, won the hopes of the majority of Ukrainians.

The manipulative factor in this election was evident. Perhaps, with the transition to the information society, the strengthening of the political-technological component is an objective law that is typical not only for Ukraine, but also for the whole democratic world. We will continue to observe a sort of a shift from the real picture of the world into a virtual one. A timely translation in the voters' consciousness through the TV series Sluha Narodu ("Servant of the People") of the image of Holoborodko, a young, honest, selfless teacher who boldly criticizes the authorities, made it possible to propose a virtual ideal of the future head of state. Subconsciously, voters extrapolate the virtues of Holoborodko to the personality of Zelenskyi, plunging into the virtual and confusing him with political realities. Probably, the electoral majority was ready to accept the populist promises of $\mathrm{V}$. Zelenskyi "all at once" more than to the appeals of P. Poroshenko concerning the need to mobilize against external aggression.

Populism has won; it was the general background of the whole election campaign. It should be noted that in the everyday language the word "populism" (from Latin populis - people) has a mostly negative connotation. However, as we see, the relevant behavior model is not only viable but also quite effective among other democratic forms of interaction between authorities and citizens. Paradoxically, but perhaps because of this, the populist approach satisfies all sides: the leaders - because they have the opportunity to control the situation, and the masses - because they hear what they want to hear.

The history of populism dates back to 1891: the date when the first populist party in the world emerged in the United States, which put forward some prototypes of democratic ideas: the struggle for tax reduction, an eighthour working day, and the provision to workers of the remnants of land that was not cultivated and was owned by large corporations. The average person was fond greatly of the similar views, but 17 years later, the populist party disintegrated. Since the end of the 19th century, populist slogans and rhetorical instruments have been improved greatly, and in course of time, the term "populism" has acquired a negative connotation, losing the poetic shade of aspiration for equality, justice and welfare of the people.

Today, populism is understood "flirting" with the masses, manipulating values and beliefs popular among people, and also a play of words, which should explain complex problems with simple and understandable words. It is this strategy, which emphasizes that participation in the political process is a civic duty of all people, whose interests are principal and primary, is the most effective during the election campaign, because it gives voters a sense of their personal significance, and therefore, the hope to solve important and pressing issues.

In any case, the centerpiece of the populist outlook, the corresponding economic and social policy, should be the happiness of the average person, his/her material wellbeing and spiritual harmony. According to the English scholar D. MacRae, the core of populism is "a person, first and foremost, his/her moral aspect" (Macrae, 1969: 159). The only society which is recognized is the one which is just, and where each individual lives wealthy and is satisfied with his/her condition. Such simplification or "romantic primitivism" is the essence of the ideology of populism that generates anti-intellectualism, that is, according to MacRae, "a poor, albeit influential type of thinking" (MacRae, 1969: 162-163). Populism is deprived of fundamental values; it often occurs as a situational reaction to crises or modernization processes, and its media are like a chameleon who adapts to the color of the environment.

By the way, populist slogans are put forward by ideologists of both authoritarian and totalitarian states, as well as liberal ones. But if the socialists recognize the revolutionary way of achieving this goal, the liberals find their ground on the self-regulatory properties of the market, populism hopes for the possibility of realizing such harmony through radical but non-violent reforms in society. It should be emphasized that populism is widespread not only in Ukraine - this phenomenon is inherent in all modern democratic countries; the populist triumph is evident in the results of the presidential and parliamentary elections in the United States, France, Italy, as well as the influence of populist parties and movements, including the scandalous PEGIDA in Germany, JOBBIK in Hungary, PODEMOS in Spain, SYRIZA in Greece, Five Star Movement in Italy.

Thus, on the one hand, populism is a "type of political consciousness or political activity, which aims to provide a broad policy in the masses at the cost of demagogy and unreasonable promises. A characteristic feature of populism is direct contact between leaders who have the ability to influence the mind and will of people and the masses. On the other hand, populism is a complex of political reactions of an individual (masses) to systematical ignoring of their interests and needs by the elite. In the political life of society, it manifests itself in the form of actions of civil disobedience, various campaigns, and crusades against the authorities" (Herasina, Pohribna, Polishchuk, 2015: 546).

Populist politicians usually use the following methods: an appeal to the content of everyday mass consciousness; simplicity of perception of social life, immediacy of perception, maximalism, readiness to follow a strong leader; efforts to be fully adapted to the needs of society; the emphasis on the accessibility and comprehensibility of the proposed measures, the priority of simple decisions; speculation on the expectations of citizens about quick and easy ways to solve problems; direction of dissatisfaction of society to the pro-government social institutions; commitment to individual freedom and morals as opposed to collegial and compromise systems; manipulation of the desire of the large masses to simplify everything; manipulation on "expectations" of the people; the use of unsolved most painful pressing problems to have constant power over the dissatisfied majority; manipulation of public opinion.

Populists demand "restoration" from the state, but they do not trust the state and the bureaucracy and rely on public and personal virtues. Primitivism inevitably has a certain hint of anti-intellectualism. In our opinion, the aspiration to simplify everything in order to be clear to the masses is perhaps the most destructive quality of populism. Populists usually insist on the need for "direct democracy", that is, the direct participation of the masses in the management of the state, the formation of a "special connection" between the electorate and the charismatic leader, on the definition of "cure-all" - the only remedy for all social diseases (Dodonov, 2017). Speaking about Ukrainian 
political life, almost all political parties are "infected" with populism, and all presidential candidates are also in captivity of populism.

Based mainly on emotional foundations, populist activists clearly define the goal and point at the enemies that prevent from reaching it, but they do not determine the means to achieve this goal. This makes the populist ideology utopian. Populists intuitively feel that their actions are in an objectively correct direction, but, being carried away by everyday troubles (victory in the election of their leader, liquidation of competitors, creation of a positive image for their own party, etc.), they often leave their ultimate goal neglected. As a rule, there is no prediction of the desired result and calculations of the resources required for this. This is what is happening now in Ukraine, when they say what will be done, but they do not say how it will be done, and what solutions they suggest to the problems. In this case, it is appropriate to recall the Hegelian classification of possibilities, namely: real, with all the necessary conditions developed for their implementation; abstract, with low probability of implementation; and impossible, with zero probability of implementation. Prior to giving "pie in the sky" to people, politicians must agree on the possibilities and means of implementing the proposals.

However, despite the fact that populism is not a new phenomenon in politics, today it is being actively dispersed owing to such a phenomenon as the post-truth.

One of the compilers of Oxford Dictionary Casper Grathwohl stressed that "the post-truth" could become "one of the defining words of our time." "An adjective relating to circumstances in which objective facts are less influential in shaping public opinion than emotional appeals," the compilers of the dictionary explained ${ }^{1}$.

Professor at Université Paris II Panthéon-Assas Philippe de Lara in his lecture "Propaganda in the Post-Truth Era", read in Kiev, at the Hryhorii Skovoroda Institute of Philosophy of the National Academy of Sciences of Ukraine on April 17, 2018, gave an example about a French reporter who covered the events of the Revolution of Dignity and had several informants among the Kyiv residents who had been permanently at the Maidan. At the end of January 2014, his informant suddenly announced at night that American tanks have been coming at Khreshchatyk, she already heard the rumble of motors, i.e., the USA began an intervention in Ukraine. Stunned by sensational news, the reporter began to seek confirmation of a message from another source, as he was taught and as the canons of western journalism demand, and of course, found nothing. While in Paris, the reporter concluded: either the operation of the US Army was super-secret, or the Kiev informant's message was not true. Of course, the news was not confirmed in the morning, and the reporter contacted that woman in Kiev to explain the reasons for providing false information, to which she replied: "I see this way, you have your own truth in Europe, and here we have ours."

To find out the essence of "post-truth" correctly, we formulate a logical chain of concepts: verity - truth - posttruth.

The phenomenon of truth belongs to the higher values of human life and conceptually agrees with the notion of verity. The most common understanding of verity is the relevance of judgments to the real state of things. Classical tradition describes verity by the notion of "absoluteness", "relativity", "objectivity", and "concreteness". In this case,

\footnotetext{
1 Oksfordskyy slovnyk nazvav "postpravdu" slovom roku. URL: https://www.bbc.com/ukrainian/society/2016/11/161116_word_of_the_year_sm
}

knowledge has always been correlated with actual facts. In this way, verity acquired the form of a genuine knowledge, retaining the status of the only true one.

In the information sphere, genuine knowledge transformed into true information about the real state of affairs.

Truth has always correlated with the verity, showing the nature of moral power (accord). In contrast to the objective fundamentalism of the unchanging verity, the truth discursively expressed its dynamic subjective versions, therefore, there are many worlds of truth. Hence, in the informational and communicative area, individuals usually defend "their" truth, argue about it and seek to identify it with the verity.

By now, academic interpretations of verity have been clearly divided into two irreconcilable positions. The first one is a modernist understanding which elevates genuine knowledge to an adequate reflection of the objective world. Hence, the very knowledge (information) is considered objective, based on "pure" verified facts. Despite this, the fact and its interpretation in the information area were clearly separated: the facts were considered self-sufficient, and interpretations were divided into true judgments and false ones. Therefore, for the political culture of the modern era, the availability of a public information field was important, where statements / information were checked for credibility. The trueness of the information, thus, was justified, and the erroneous information (disinformation) was exposed as proofless, refuted, and condemned from a moral correct position.

The second one is postmodern interpretation which denied the truth to exclusivity and fundamentalism, asserting a lot of conditional verities. Postmodernism avoids the classical understanding of verity, since this trend denies the binary opposition of the object and subject of knowledge. A text is considered as a single subject matter that is interpreted as the primary reality without correlation with any extra-lingual reality. That is why the problem of trueness is replaced by the problem of interpretation. The usual concepts - conformity, adequacy, correctness, reflection lose their significance. The verity is understood as an "army of metaphors". In the postmodern vision, the media reality contains simulacra instead of true descriptions that do not reflect the true state of affairs and are fabricated media events. Of course, "informational reality" in its essence has not changed, but the attitude towards information, which is expressed in the above-mentioned positions, has been transformed. Therefore, "information reality" is only a version of objective reality, a kind of part of the truth.

All this in aggregate creates a deep, first of all, intrapersonal conflict, which manifests itself in all spheres of interaction, which predetermines the state of constant emotional stress which is so necessary for the world of "post-truth".

The Internet facilitated the wide spreading of the posttruth, which allows each user to become a journalist, blogger, but without an "editor-in-chief" who would evaluate information in terms of trueness. In the modern world of accelerated information consumption, new technologies of constructing and spreading the post-truth are created: a) personification of politics (the identity of a political leader becomes more important than the ideas of a political leader); b) emotionalization of politics (the rapid development of the Internet contributes to shifting the focus of the audience's attention to emotions and feelings); c) entertaining politics (simplification and schematization of complex themes combined with the humorous presentation of information leads to the emotional perception of politics in general). Modern reality, including political, is prone to 
simplification, primitivization, naivety, and visualization. Usually it is difficult to think rationally, it is necessary to analyze, compare, and therefore an individual aspires to simplify - they showed a picture, or an eye-catching video, and a "soul of the voter" is pleased.

The unit-carrier of the post-truth in the Internet is a meme. According to Richard Dawkins, the meme is a unit of cultural information that is spread from one person to another through simulation, training, etc. (Dawkins, 2006). Analyzing the course of the election campaign, it is difficult to underestimate the role of Facebook or Twitter networks, which were the main source of political information for a significant number of people.

It is appropriate to recall the huge number of memes with V. Zelenskyi, who made a statement on the New Year's night that he would run for the post of head of state. Already in a few minutes, memes with him were seen by Ukrainians and residents of neighboring countries. Internet users unknowingly joined the election agitation, instantly sharing this news. When sharing information, the level of trust in content increases, but the occurrence and circulation of fake information is not taken into account. Today, most of the memes are created by simple users, and political technologists have the opportunity to influence people's minds using "funny pictures". So, a meme should be considered as a unit of manipulation of consciousness.

There are various types of Internet memes: language cliches (quotes, paremias); visual and audiovisual items (photos, pictures, videos); images of real or fictional media characters; brands of companies or goods; thematic dominant ideas of media landscape. The following features are typical for Internet memes:

- use of colloquial speech, which allows it to be "alive" and accessible to any user. The basis of the meme is always one fact-event;

- the choice of this fact is not objective and involves a hidden meaning. Post-truth works based on a similar principle. The recipient obtains an already defined response to a certain fact, without analyzing it, if this unit of information may be integrated in the structure of its political consciousness. He/she accepts it without thinking;

- emotional effect. The main function of the meme is affective, which makes it similar to the mechanism of work of the post-truth. Meme appeals to emotions of laughter, irritation, etc.

- exaggeration of minor details. The creators of the memes appeal to various aspects of the life of political factors. They relate to the attributes of appearance, peculiarities of behavior, statements of participants of the presidential race;

- formation of public opinion. Having conciseness, simplicity, emotionality, and humorousness, memes instantly attract the attention of an individual and remain in his/her memory for a long time. These same features help to instantly distribute memes on the Internet;

- the speed and ease of creation (there are special meme generators) make an online meme always timely and extremely relevant. The memes make it possible to react promptly to events and interpret them in the necessary way;

- Detabooing. Active use of obscene words and thus the removal of prohibitions (ethical, religious, political) amidst almost absolute zero censorship provides the Internet meme with detabooing. The "eternal" traditional truths are destroyed by the impudence of the Internet meme;

- Internet memes received by the user, as a rule, correspond to his/her worldview. Individuals choose themselves the groups to subscribe, i.e., there is a creation of an information cocoon, which constantly confirms the opi- nion of followers, including by means of memes (Bortnikov, Pungina: 38-40).

In the 2019 presidential election, a stable dynamics of aggression in memes may be observed. The most widespread memes about P. Poroshenko - "Tariff genocide", "Poroshenko is an alcoholic", "Government makes profit out of war" - moved from haters groups in Facebook to pre-election rhetoric. V. Zelenskyi caught it bad as well. There is a whole selection of caricature memes about Zelenskyi called "ZeliVova-ZeliBoba" on the Internet. The memes contributed to the creation of images of the irreconcilable enemies who run for the post of the head of state. A virtual opponent begins to acquire many information characteristics that are not peculiar to him, but known to everyone; it appears that he is awful and this enemy must be fought back.

\section{Conclusions}

Analyzing the course of the presidential elections in Ukraine, the following points should be noted.

1. Electoral consciousness of Ukrainians turned to be open to political constructionism and perception of virtual images, which, accordingly, made provision for an enhanced manipulative component. If to put off emotional eruptions in the social media of supporters of both candidates, it should be noted that the presidential election campaign as a whole caused diametrically opposed sentiments in society: on the one hand, it was the pride of being a truly democratic country, on the one hand, it was astonishment, fear, shame and outrage that majority of people became an easy prey for political technologists.

2. Those candidates who appealed to irrational motives, gave promises regardless of the possibility to implement them, had the biggest chances to win. Potential "servants of the people" said what people wanted to hear, not even considering that "simple, quick decisions" contradict the objective tendency to complicate the content and increase the dynamism of modern political processes, and hence the impossibility to solve all problems here and now. Therefore, populism was almost the essential component of almost all candidates for a presidential post.

3 . The post-truth phenomenon became an effective method of manipulating electoral thought. It's much easier and more efficient to achieve what you want, appealing to the emotions of the public rather than relying on dry facts, hoping that the general public will interpret them correctly. However, both post-truth and populism most strongly manifest themselves during the political crisis; the deeper it is, the more terrible weapons in the hands of a clever politician post-truth becomes. In times of political stability, populism loses its magic power, since the absence of a demand for radical changes in the state of the population makes it simply unnecessary.

4. The 2019 pre-election presidential campaign is a campaign with the use of a huge Internet resource, and brutal social media battles between "porokhobots" ("bots of Poroshenko") and "Ze-bots" ("bots of Zelenskyi") with the help of memes. Ukrainian people again fell out with each other, as it was in 2004 and 2013/14. Judging by the content of posts in social media, it will be difficult to overcome the electoral split in a society which is already involved in early parliamentary elections.

5. The tandem of populism and post-truth is a feature of political processes peculiar not only to Ukraine but also to many countries around the world. Populism and posttruth are identical in the following aspects: a) appeals to emotions and personal beliefs of the audience (without focus on the details); b) deliberate omission of objective facts; only a portion of information is provided, while the 
other is concealed; c) infoglut, broadcasting of a continuous stream of news, the main part of which consists of abstract considerations; d) combination of truth and falseness; e) the emergence of information at the "right" time, i.e., when it is expected the most; e) provoking a backlash of the audience using the "sensational" semantic charge of the content of the post-truth.

6 . Though the tandem of populism and post-truth are the essential features of political life, but in general, it is a negative phenomenon. The spread of the latter evidences the low level of political culture, separation from reality, hope for a miracle, and political infantilism. Indeed, young people took an active part in the presidential election, which in the majority voted for a new person, a new man, a new political player. Without denying that our young people are smart and creative, one must admit that they, and, indeed, the majority of the Ukrainian people, have mediocre knowledge of the powers of the President, the Chairman of the Verkhovna Rada and the Prime Minister, which evidence political ignorance. To prevent our people from admiration for populism, Ukrainians should be provided with political education and critical thinking formation, which they can "use" when making landmark decisions. In general, the new political reality requires scholarly reflection from theoreticians, and a thoughtful attitude to politics from general public.

\section{REFERENES}

Fukuyama, Fransis (2019). Politychnyy poryadok i politychnyy zanepad. Vid promyslovoyi revolyutsiyi do hlobalazatsiyi demokratiyi (translat. from English). Kyiv: Nash format, 608 p. (In Ukrainian)

Abazi, H. (2017). On the background and the possible impact of epistemology on the emergence of the post of truth. Thesis No. 3, Retrieved from https://clck.ru/GpVvz (Accessed: 13.05.2018).

Kirkpatrick, A. (2017). Understanding in a post-truth world: comprehension and co-naissance as empathetic antidotes to posttruth politics. Cosmos and History: The Journal of Natural and Social Philosophy. Vol. 13, no. 3. P. 4-28. (In English)

Gellner, E. \& Ionescu, G. (1969). Populism: It's Meanings and National Characteristics. London: Weidenfeld and Nicolson, 347 p. (In English)

MacRae, D. (1969). Populism as an Ideology. Populism: Its Meanings and National Characteristics. London, Pp. 347. (In English)
Herasina, L. M. and Pohribna, V. L. and Polishchuk, I. O. and other. Trebin. M. P. (ed.) (2015). Politolohichnyy entsyklopedychnyy slovnyk. Kharkiv: Pravo, 816 p. (In Ukrainian)

Dodonov, D. (2017). Fenomen populizmu v suchasnomu politychnomu prostori. Hileya: naukovyy visnyk (Kyiv). Issue 123 (8). Pp. 287-292. (In Ukrainian)

Dawkins, Richard (2006). The Selfish Gene. Oxford University Press, USA; 3rd edition, April 24. Pp. 192. (In Ukrainian)

Bortnikov, N. A. and Pungina, A. P. (2017). Vizualnyy politicheskiy internet-mem kak instrument postpravdy. Politika postpravdy $v$ sovremennom mire. St. Petersburg: Scythia-print, P. 3840. (In Russian)

\section{LIST OF REFERENCE LINKS}

Фукуяма Френсіс. Політичний порядок і політичний занепад. Від промислової революції до глобалазації демократії: (пер. $з$ англ. Тарас Цимбал і Роман Корнута). Київ: Наш формат, 2019. 608 c.

Abazi $\mathrm{H}$. On the background and the possible impact of epistemology on the emergence of the post of truth. Thesis No. 3 , 2017. URL : https://clck.ru/GpVvz (Дата звернення: 13.05.2018).

Kirkpatrick A. Understanding in a post-truth world: comprehension and co-naissance as empathetic antidotes to post-truth politics. Cosmos and History: The Journal of Natural and Social Philosophy. 2017. Vol. 13, no. 3. P. 4-28.

Gellner E., lonescu G. Populism: It's Meanings and National Characteristics. London: Weidenfeld and Nicolson, 1969. 347 p.

MacRae D. Populism as an Ideology. Populism: Its Meanings and National Characteristics. London, 1969. P.347.

Політологічний енциклопедичний словник / уклад.: [Л. М. Герасіна, В. Л. Погрібна, І. О. Поліщук та ін.]; за ред. М. П. Требіна. Харків: Право. 2015. 816 с.

Додонов Д. Феномен популізму в сучасному політичному просторі. Гілея: науковий вісник. Збірник наукових праць. 2017. Вип. 123 (8). С. 287-292.

Dawkins Richard. The Selfish Gene. 3rd edition. USA: Oxford University Press, 2006. p. 192.

Бортников Н. А., Пунгина А. П. Визуальный политический интернет-мем как инструмент постправды. Политика постправды в современном мире: Сборник материалов по итогам Всероссийской научной конфреренции с международным участием 22-23 сентября 2017 года / под ред. О. В. Поповой. Санкт-Петербург: Скифия-принт, 2017. С. 38-40.

\section{Додонова Віра,}

Київський університет імені Бориса Грінченка (м. Київ, Україна)

e-mail:v.dodonova@kubg.edu.ua,ORCID 0000-0002-4282-5495

\section{ТАНДЕМ ПОПУЛІЗМУ І ПОСТПРАВДИ ЯК ТЛО РОЗВИТКУ СУЧАСНОЇ ДЕМОКРАТІЇ В УКРАЇНІ}

Емпіричною базою для політичної фрілософії завжди були політологічні теорії та концепції, що описують реальний політичний процес. На думку авторки, президентська виборча кампанія 2019 року в Україні найкраще може бути усвідомлена та описана за допомогою концептів "популізм" та "постправда". У статті аналізується дискурс поняття "популізм", розкривається його зміст та основні риси. Підкреслюється необхідність встановлення громадянського контролю за діями влади як засобу протидії популізму. 3'ясовуються сутнісні характеристики феномену постправди. Наводиться теоретичний ланцюжок термінів "істина""правда"-"постправда". Аналізується мем як одиниця постправди. Доводиться, що саме зв'язка популізму та постправди були тлом електоральної свідомості, на якому розгорталися маніпулятивні передвиборчі технології президентської кампанії в Україні.

Ключові слова: демократія; вибори; популізм; постправда; мем.

(C) Dodonova Vira

Надійшла до редакції: 16.05.2019

Прийнята до друку: 10.06.2019 